\title{
sciendo
}

DOI 10.2478/sbe-2019-0013

SBE no. 14(1) 2019

\section{RELEVANCE OF BIG DATA FOR BUSINESS AND MANAGEMENT. EXPLORATORY INSIGHTS (PART II)}

\author{
OGREAN Claudia \\ Lucian Blaga University of Sibiu, Romania
}

\begin{abstract}
:
Over the last few decades Big Data has impetuously penetrated almost every domain of human interest/action and it has (more or less consciously) become a ubiquitous presence of day to day life. The main questions this exploratory paper seeks to address (throughout its two parts) are the following: What is the (actual) impact of Big Data on Business \& Management and How can businesses (through their management) leverage the potential of Big Data to their benefit? This second part of the paper is dedicated to the investigation of the demand-side of the big data industry - by highlighting some evidences (and projections) on the impact of big data analytics on Business \& Management (both at aggregate and granular level) and exploring what companies could and should do (through their management) in order to best capitalize on the opportunities of big data and avoid/minimize the impact of its threats.
\end{abstract}

Key words: Big Data, Business Analytics, Value, Business, Management

\section{Introduction}

Both cause and consequence of (especially technological) development, Big Data has become a defining and ever-growing feature of nowadays' environment, vector of global transformations in (almost) all the areas of human concern (including everyday life). In order to (further) evaluate the relevance of Big Data for Business \& Management, the first part of the paper has performed a concise history of the topic Big Data as reflected in academia and a critical content analysis of the Big Data concept, followed by an examination of the most significant realities and trends that characterize the supply-side of the Big Data industry and its main players; the following conclusions of the first part of the paper serve as background for this second part of the paper (Ogrean, 2018):

Firstly, the Big Data concept (still) lacks an unanimously accepted definition (as the analysis of the definitions provided by the literature reveals at least three streams of thought: a technical / operational based approach, a dimensions / characteristics based approach, and a holistic value based approach); but, besides the diversity of opinions on 
Big Data conceptualization, academia provides also some significant congruencies regarding the (main) characteristics of Big Data (volume, velocity and variety), and the (huge and still far from being reached) potential of Big Data (analytics) to deliver (different kinds of) value.

Secondly, an increasing number of records have documented (the real-life developments registered by) Big Data: since 1993 - when the first reference to the topic Big Data has been made into a paper - to the end of 2017, the WoS Core Collection has gathered a total of 25,839 results for the "big data" topic; a similar (exponential) evolution of entrances has been registered by WoS as regards the Management (755 records between 2006 and 2017) and Business (613 records between 2004 and 2017) WoS Categories.

Thirdly, Big Data has emerged as a flourishing (new) industry, providing - through the solutions and tools it develops within its different segments (software, hardware and services) - a (global) ecosystem of support for a variety of other industries; the big data market revenue worldwide is projected to grow from $\$ 35$ B in 2017 to $\$ 103$ B in 2027 (Kobielus, 2018) - almost tripling its value, while the inner (structural) different dynamics of its components will reflect a tendency towards industry maturation - fueled by both the supply-side of the industry (especially through technological advancements and competitive positioning) and the demand-side of it (through the crystallization and development of their needs - based on the perceived benefits of big data analytics).

Fourthly, the above-mentioned tendency towards market maturation is confirmed if looking at the main players on the Big Data and Analytics market - as "early vendors that represented the mix-and-match open source approach continue to have modest success taking their leading-edge customers into wide-scale production. But vendors of increasingly integrated platforms as well as semi-custom applications are growing faster and moving up the ranks" (Burris, 2018).

This second part of the paper is dedicated to the investigation of the demand-side of the big data (analytics) industry - by highlighting some evidences (and projections) on the impact of big data analytics on Business \& Management (both at aggregate and granular level) and exploring what companies could and should do (through their management) in order to best capitalize on the opportunities of big data and avoid/minimize the impact of its threats.

\section{Big Data (and Business Analytics) - the Demand-Side of the Industry: broad evidences on the adoption of big data by businesses}

The recent dynamics of the revenue from Big Data and Business Analytics (BDA) solutions worldwide, coupled with the projections on their (exponential) growth in the years to come - estimating "a compound annual growth rate (CAGR) of 11.9\% over the 20172022 forecast period" (IDC, 2018) - (Fig. 1) substantiate the businesses' (and their managers) increasing awareness on the challenges of big data, while confirming their growing interest in capitalizing on the opportunities these challenges might provide. The risks/threats of not acknowledging the challenges big data are raising in front of businesses and/or (of) not timely and properly addressing them are something these 
numbers do not reveal, but they strongly suggest: as big data (with its plethora of known and yet to be discovered business applications and tools) are here to stay, the early adopter of this megatrend businesses are not only benefiting from the advantages of the first movers, but (given the high complexity of the phenomenon and its rapid propagation speed) they are also likely to deepen the gap that separates them from the left behind businesses, while shaping new evolution paths for industries and setting new industry standards.

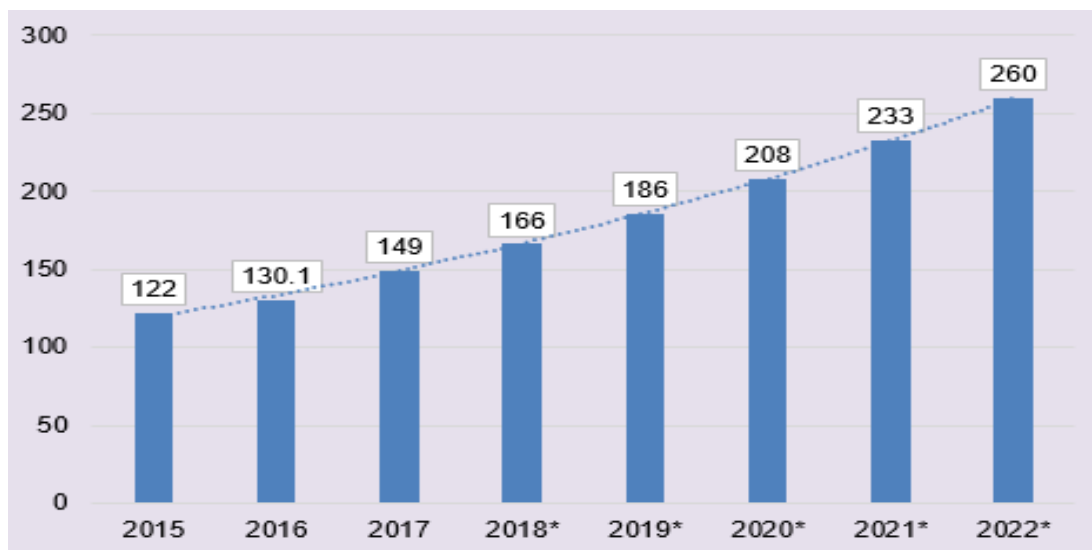

Fig. 1. Revenue from big data and business analytics solutions worldwide from 2015 to 2022 (\$ B) Source of data: IDC apud Statista

On a worldwide market valuated at about \$166 B in 2018 (IDC, 2018), the analysis of BDA market distribution worldwide by industry (Fig. 2) shows that banking, discrete manufacturing and process manufacturing are the most preeminent players on the demand-side, and they are closely followed by professional services (and federal/central government); together, these five leading industries are counting for almost a half of the total investments in BDA. Therefore, particularly within these industries it is most likely for BDA to have emerged as sources of competitive advantage for the (pioneer and agile) companies embracing them and ticking the four VRIO characteristics recommended/requested by the resource-based model - value, rarity, inimitability, and organization (Rothaermel, 2017). But, once gained, and in order for this advantage to be maintained, businesses have to be aware of the wide areas of potential contribution BDA have to a company's value creation (yet far from being completely valorized), on the one hand, and of the businesses' continuous need for dynamic resources, competencies and capabilities (therefore further investments), on the other hand.

Comparative to 2016 (when the market was valuated at about \$130 B) (IDC, 2017 apud Statista): (a). the "others" category has fallen - from $51.7 \%$ to $51 \%$; (b). banking, discrete manufacturing and process manufacturing have kept their Top 3 positions (with banking and process manufacturing increasing their relative contribution - from $13.1 \%$ to $13.6 \%$ and from $8.4 \%$ to $8.7 \%$ respectively - and discrete manufacturing decreasing their relative contribution - from $11.9 \%$ to $11.7 \%$ ); (c). professional services (increasing from a $7.4 \%$ contribution to a $7.9 \%$ contribution) have taken the forth position - previously 
occupied by federal/central government (whose relative contribution has decreased from $7.6 \%$ to $7.1 \%$ during the reference period).

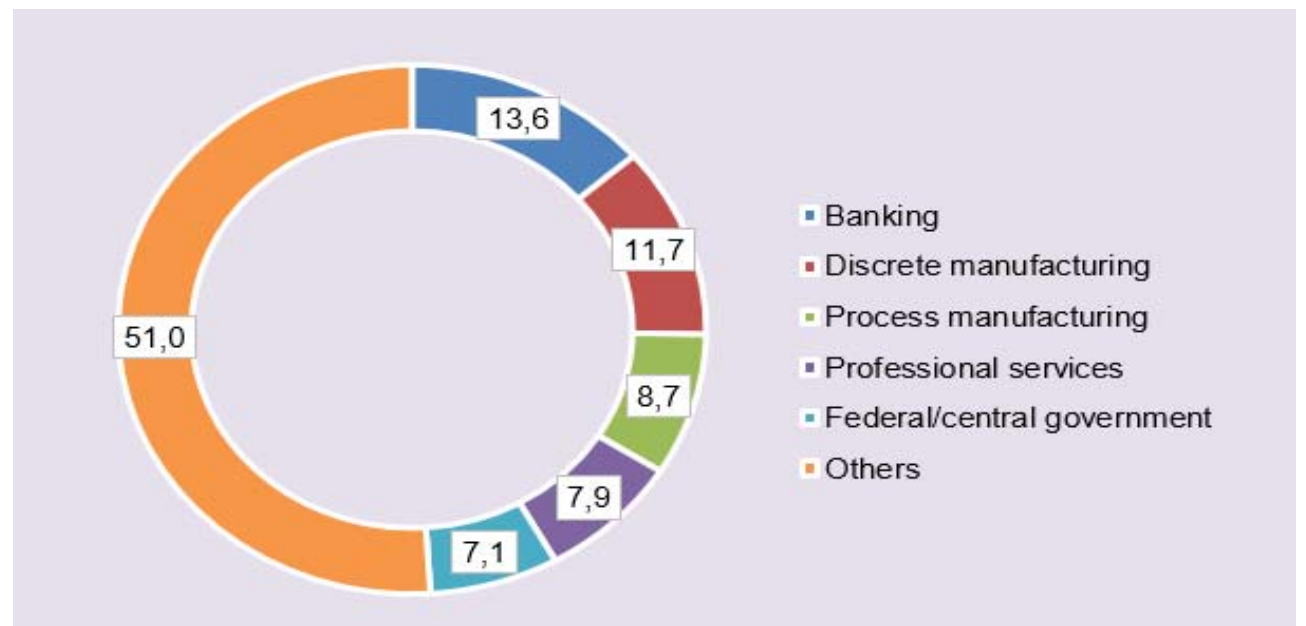

Fig. 2 Big data and business analytics market distribution worldwide 2018 by industry (\%)

Source: IDC apud Statista

In terms of the "Industries targeted by big data analytics application developers, as of 2016", a worldwide survey of 1441 respondents - "developers actively creating new applications with the latest technologies" answering the question "which best describes the industry that will be targeted by the application that uses big data analytics?" - reveals (Fig. 3) the wide spectrum of industries that BDA applications may cover (while suggesting a multitude of underexplored areas); amongst these industries, the Internet of Things (15.1\%), Professional, scientific, and technical services (non-computer related) (10\%), and Telecommunications (10\%) make the Top 3, and they are closely followed by Manufacturing (non-computer-related) (9.6\%) and Finance or insurance $(9.4 \%)$.

The ever increasing spread of BDA throughout the entire spectrum of industries, spirally coupled with the technological advancements in the supply-side of the Big Data industry, are likely to determine transformational shifts both within businesses and across them, while changing the entire "industry architecture" as we know it today. Less than a decade is necessary, according to McKinsey Analytics (2018), until "new ecosystems are likely to emerge in place of many traditional industries"; the 12 ecosystems that will define by 2025 both the retail and institutional spaces are: B2B marketplace; B2B services; Global corporate services; Wealth and protection; Public services; Health; Digital content; Housing; Education; Mobility; Travel and hospitality; and B2C marketplace. 


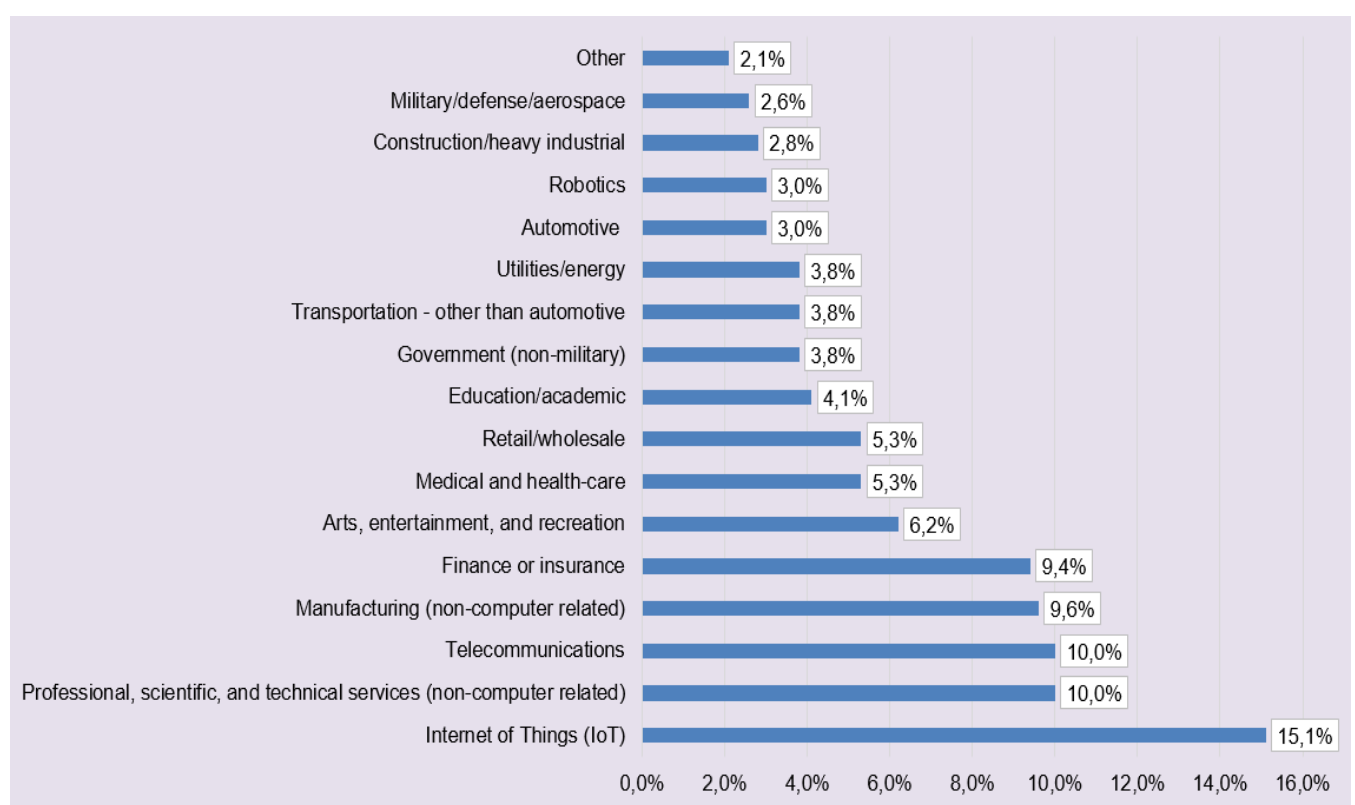

Fig. 3 Industries targeted by big data analytics application developers, as of 2016 Source of data: Forbes, apud Statista

Until then:

- the 2017 Dresner Advisory Services' Big Data Analytics Market Study ("based on a cross-section of data that spans geographies, functions, organization size, and vertical industries") highlights the following: (1) in terms of geography: more than a half of the North American (55\%) and EMEA (53\%) based companies are currently using big data, while the Asia Pacific ones register a lesser than a half degree (44\%); (2) as regards industries: the current use of big data is reported by $87 \%$ of the respondents from Telecommunications, $76 \%$ of those from Financial Services, and $61 \%$ of those from Technology; (3) by function: all departments are big data adopters - with IT, R\&D and Business Intelligence Competency Center being on top (more than 50\% usage), Executive Management and Sales and Marketing - at the middle (between 30 and 50 percent) - and Finance - at the bottom (with less than $10 \%$ big data adoption); (4) as concerns big data use cases: Data warehouse optimization occupies the first place ("while considered 'critical' or 'very important' to about $70 \%$ of respondents"); "'Customer/social analysis' and 'predictive maintenance' are the next most likely use cases that are, at minimum, 'very important' to a majority of respondents"; lesser usage register Clickstream analytics, Fraud detection, and loT (Dresner Advisory Services, 2017);

- the 2017 McKinsey's Global Survey on data and analytics (based on insights coming from "530 C-level executives and senior managers representing the full range of regions, industries, and company sizes") brings to light the following findings: (1) "Data and analytics are changing the way business is done" - in terms of both "companies' core business functions", and "the nature of industry competition; (2) "Data monetization is becoming a differentiator" - as "monetization is already more prevalent in certain industries" (basic materials and energy, financial services, and high tech"), 
on one hand, and "compared with their peers, high performers report a greater variety of actions to monetize data - with greater revenue impact", on the other hand; (3) "Get the foundations right first" - by considering that "analytics leaders [companies that, according to respondents, have seen at least a 6 percent impact on their revenues and costs from their data-and-analytics activities in the past three years] differ from other companies in their data-and-analytics strategy, structure, and executive attention" (McKinsey Analytics, 2018).

\section{Big Data (and Business Analytics) - the Demand-Side of the Industry: granular insights on the evolution of big data adoption}

Starting in 2012, NewVantage annually releases the results of its Big Data Executive Survey - initiated in order to serve as benchmark for companies aiming to better understand (and adjust to) the realities and trends characterizing this growing phenomenon. Thus, the historical comparative analysis of results (2018 versus 2012) is likely to provide a systematic (and more granular) view on: (1) the main challenges the emergence and development of big data (and business analytics) have raised in front of businesses (and the ways they have been perceived by managers); (2) the dynamics of the ways businesses, through their managers, have been addressing those challenges (by investing in and using big data analytics in order to create value for companies); and (3) the "unsolved businesses" and "ways ahead"; Table 1 bellow is synthetizing the main insights.

Table 1 NewVantage's Big Data Executive Survey - exploratory insights

\begin{tabular}{|c|c|}
\hline $\begin{array}{l}\text { Big Data Executive Survey } 2012 \\
\text { (NewVantage, December 2012) }\end{array}$ & $\begin{array}{l}\text { Big Data Executive Survey } 2018 \\
\text { (NewVantage, January 2018) }\end{array}$ \\
\hline \multicolumn{2}{|c|}{ Big data - working definition of the concept } \\
\hline \multicolumn{2}{|c|}{$\begin{array}{l}\text { - 2012: "Big Data is a term used to describe data sets so large, so complex or that require } \\
\text { such rapid processing (...), that they become difficult or impossible to work with using } \\
\text { standard database management or analytical tools. Manipulating data sets like these often } \\
\text { require massively parallel software running on tens, hundreds, or even thousands of } \\
\text { servers" (NewVantage, 2012). }\end{array}$} \\
\hline \multicolumn{2}{|c|}{ Survey's aim } \\
\hline $\begin{array}{l}\text { - To "explore the issues and business trends } \\
\text { in America's leading companies relating to } \\
\text { Big Data“. }\end{array}$ & $\begin{array}{l}\text { - "To understand how Big Data and Al are } \\
\text { driving business innovation". }\end{array}$ \\
\hline $\begin{array}{l}\text { - The } 2018 \text { survey has acknowledged and int } \\
\text { data and its business applications - as it cor } \\
\text { Al as being on a continuum"; } \\
\text { - The same evolution is captured in terms of } \\
\text { the } 2012 \text { survey emphasized on the emerge } \\
\text { its threats - the plethora of "issues and } \\
\text { capitalized on by businesses, the } 2018 \\
\text { emphasizing on the opportunities big data } \\
\text { business innovation"; } \\
\text { Consequently, the survey's aim (as it was st } \\
2012 \text { (when big data were perceived as an e }\end{array}$ & $\begin{array}{l}\text { grated the evolution of both the concept of big } \\
\text { siders "traditional data analytics, Big Data, and } \\
\text { ositioning against the challenges of big data: if } \\
\text { nce of the big data phenomenon and (mainly) } \\
\text { business trends" still to be discovered and } \\
\text { urvey reveals a totally different perspective, } \\
\text { ould bring to businesses - in terms of "driving } \\
\text { ted by NewVantage) was rather exploratory in } \\
\text { nerging, but possibly temporary trend), while it }\end{array}$ \\
\hline
\end{tabular}


was rather explanatory in 2018 (as the big data megatrend has started to crystallize).

\section{Survey's universe, main research question and behest}

- "Over 50 executives representing leading $\mid$ • "Nearly 60 Fortune 1000 or industry Fortune 1000 companies and large Federal leading firms". agencies".

- $\quad$ By resorting to the same research universe (and about the same sample size), the study ensures the comparability of results, while allowing and favoring the extracting of valuable insights on the dynamics of BDA's impact on business and management;

- "For the corporate mainstream, would Big Data be a disruptive force or a passing phase?" (NewVantage, 2018) - a general (but quite powerful and catchy) question has driven the research since the beginning of the endeavor in 2012, highlighting the growing potential of BDA to change the evolution paths of other than tech specialized businesses and industries;

- $\quad$ "The survey was conducted at the behest of a group of senior Fortune 1000 executives who sought to understand this new thing called Big Data, and understand its emerging impact on the corporate mainstream, in contrast to the emerging Tech Giants for whom data was their lifeblood and reason for being" (NewVantage, 2018).

\section{Industry representation and arguments}

- $\quad$ "Financial Services - 53\% $\quad$ • "Financial Services | Insurance - 77.2\%

- Insurance - 19\%

- Government - $10 \%$

- Other Business - 18\%"

- $\quad$ Pharmaceuticals | Medical $-8.8 \%$

- Other Industries - 14.0\%"

- 2012: "Financial service companies have traditionally been at the forefront of using strategic data and analytics to support their core business functions (NewVantage, 2012);

- 2018: "In addition, emerging users of data, including pharmaceutical and medical organizations, and as well as firms representing a range of industries have participated" (NewVantage, 2018) in the survey.

Demographics

- "C-Suite Executives - 30\% $\quad$ • "Chief Data Officer - 55.6\%

- Enterprise Function Heads - Head of - Chief Analytics Officer I Chief Data Analytics, Head of Informatics, Head of Scientist - $15.3 \%$ Enterprise Information - 50\%

- Data Program Head - Head of Data - CEO|President - 5.6\% Architecture, Chief Data Architect - 20\%" - Chief Marketing Officer - $2.8 \%$

- Other - 6.9\%"

- 2012: "All participants were executives with budgetary and decision-making responsibility or direct visibility and influence for Big Data initiatives" (NewVantage, 2012);

- 2018: "the largest percentage of C-Executive respondents comes from those executives who bear the most direct responsibility for corporate data initiatives" (NewVantage, 2018);

- Moreover, in 2018 "a majority of firms (63.4\%) report having named a CDO - up from 12\% in 2012" (Bean, 2018).

\begin{tabular}{|c|c|}
\hline \multicolumn{2}{|c|}{ Core Themes and Trends / Key Themes and Findings } \\
\hline $\begin{array}{l}\text { - "The promise of improved data-driven } \\
\text { decision making; } \\
\text { - } \quad \text { customers and risk are the primary focus; } \\
\text { - it's about variety, not volume; }\end{array}$ & $\begin{array}{l}\text { - } \quad \text { Mainstream firms fear disruption from } \\
\text { highly agile data-driven upstarts; } \\
\text { Big Data is empowering Al and cognitive } \\
\text { learning investment and initiatives; }\end{array}$ \\
\hline
\end{tabular}


- organizational alignment is critical to $\bullet$ people challenges loom greatest as success; firms strive to create a data-culture;

- $\quad$ the biggest roadblock may be more about people [and skills] than technology."

- the Chief Data Officer has arrived, but confusion on mandate and future persists;

- firms are investing in Big Data and Al with a goal of better analytics for decision making"

- $\quad$ The crystallization of the BDA megatrend has led to quite significant changes - as regards the core/key themes, trends/findings registered at business level - driven by the ways managers have perceived and internalized the BDA related challenges:

$\checkmark$ the biggest opportunity in 2012: getting customer insights / improving customer experience - although "17 different business functions were named as driving Big Data initiatives" (NewVantage, 2012), the customer related benefits seem to have been the "most obvious and profitable to jump on" in the early stages of BDA adoption;

$\checkmark \quad$ the biggest threat (for mainstream firms) in 2018: disruption and displacement form data-driven, highly agile competitors - although BDA have been increasingly embraced by businesses, as "virtually all of the respondents (97\%) say they are investing in these types of projects" (NewVantage, 2018), nearly 4/5 of executive respondents have expressed this concern, suggesting a perceived inability either to properly benchmark their business in terms of BDA adoption, or to deal with a "too bigger/complex challenge".

- However, the raison d'être of BDA was and still is the same: improving decision making.

\section{Strategic approach of BDA}

- $\quad$ "Leveraging Big Data to deliver business value will require a carefully focused strategy that leverages and protects existing data assets, develops new capabilities that are production-ready and reusable, and is capable of managing the deluge of new data that is created every "Those companies that prove themselves to be adept at developing and executing initiatives using Big Data and $\mathrm{Al}$ capabilities will likely be the companies best positioned to deflect threats of agile, data-driven competitors in the decade ahead" (Bean, 2018). day".

- Given the strategic business value of big data, the results of both surveys emphasize on the (widely) acknowledged need for a good "data strategy"; still, the two approaches significantly differ from each other: if the 2012 approach rather characterizes a broad/not particularly focused, internally oriented, "good to have it" strategy, the 2018 approach reflects (the need for) a much more offensive strategy, able to clearly target a strategic edge against competitors - as the BDA adoption has become a strongly competitive weapon in a variety of industries.

\begin{tabular}{|c|c|}
\hline \multicolumn{2}{|c|}{ Comparisons - in numbers } \\
\hline Big Data Investments & \\
\hline $\begin{array}{l}\text { - } 85 \% \text { of the respondents have Big Data } \\
\text { initiative planned or in progress and almost } \\
\text { half are using Big Data in some type of } \\
\text { production/operational capacity" }\end{array}$ & $\begin{array}{l}\text { - } 97.2 \% \text { of executives report that their } \\
\text { companies are actively investing in } \\
\text { building or launching Big Data and Al } \\
\text { initiatives" }\end{array}$ \\
\hline
\end{tabular}

- The evolution from "almost half" of the companies (of the reference sample) using big data in 2012 to "almost all" of them actively investing in BDA initiatives in 2018 suggests that big data have become a prerequisite for these companies' strategic approaches (no matter their

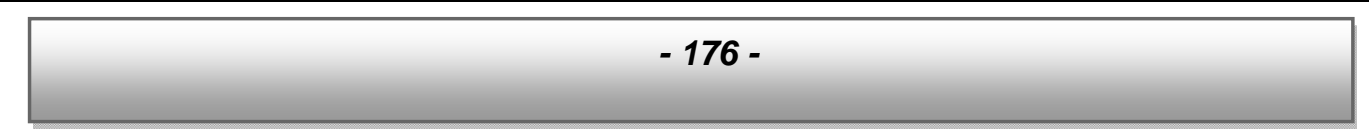


industry).

\begin{tabular}{|c|c|}
\hline Budget for Big Data initiatives: & Total investment in Big Data and Al: \\
\hline $\begin{array}{ll}\text { - } & \text { More than } \$ 10 \text { Million - } 24 \% \\
\text { - } & \$ 1 \text { Million - } \$ 10 \text { Million - } 48 \% \\
\text { - } & \$ 100,000-\$ 1 \text { Million - } 24 \% \\
\text { - } & \text { Less than } \$ 100,000-5 \%\end{array}$ & $\begin{array}{ll}\text { - } & \text { Greater than } \$ 500 \text { Million }-12.7 \% \\
& \text { (greater than } \$ 1 \text { Billion }-7.9 \%) \\
\text { - } & \$ 50 \text { Million }-\$ 500 \text { Million }-27.0 \% \\
\text { - } & \text { Under } \$ 50 \text { Million }-60.3 \% \\
& \text { (less than } \$ 10 \text { Million }-22.2 \% \text { ) }\end{array}$ \\
\hline
\end{tabular}

- Not only the relative number of companies embracing big data has increased, but also the dedicated budgets have been considerably expanded - suggesting the possible emergence of a chasm between the "big investors" in big data and the "small / not at all investors", leading to significant performance gaps and possibly the eventual extinction of the latest.

\begin{tabular}{|c|c|}
\hline $\begin{array}{l}\text { Expected benefits through } \text { Big data } \\
\text { initiatives }\end{array}$ & $\begin{array}{l}\text { Top objective of Big Data and Al } \\
\text { investments }-\# 1^{\text {st }} \text { goal \& its success rate }\end{array}$ \\
\hline $\begin{array}{ll}\text { - } & \text { "Better, fact-based decision making (22\%) } \\
\text { - } & \text { Improved customer experience }(22 \%) \\
\text { - } & \text { Increased sales }(15 \%) \\
\text { - } & \text { Reduced risk }(11 \%) \\
\text { - } & \text { New product innovations }(11 \%) \\
\text { - } & \text { More efficient operation }(10 \%) \\
\text { - } & \text { Higher quality products and services } \\
& (10 \%) \text { ". }\end{array}$ & $\begin{array}{l}\text { - } \quad \text { Advanced analytics/better decisions } \\
(36.2 \% ; 69 \%) \\
\text { - } \quad \text { Improve customer service }(23.2 \% \text {; } \\
\text { - } 53.4 \%) \\
\text { - } \quad \text { Innocrease expenses }(13.0 \% ; 60.9 \%) \\
\text { - } \quad \text { Speed to market }(8.8 \% ; 54.1 \%) \\
\text { - } \quad \text { Monetization }(7.2 \% ; 27.3 \%) " .\end{array}$ \\
\hline
\end{tabular}

- If the 2012 survey mainly emphasized on the "expected benefits" of big data initiatives (yet to be confirmed), the 2018 survey reveal quite a different status - as "nearly $3 / 4$ of the executives surveyed $(73.2 \%)$ claim that their firms have achieved measurable results from their Big Data and Al investments" (NewVantage, 2018); however, the full potential of BDA adoption seems to be far from being reached.

Challenges ahead

- Access to data - as "over half the respondents rate their 'access to relevant, accurate and timely data' as less than adequate";

- Measurement issues / assessment criteria - as "over half do not have a ROI-driven business case";

- Understanding the real potential of big data and capitalizing on it - as "most respondents are using Big Data to attack known problems (...) from known data sources";

- Embracing a holistic approach on managing Big Data - based on "organizational alignment and coordination (...), as well as solid [data management] capabilities";

- Sourcing analytical skills, filling the new role of the "data scientist" (which $70 \%$ of organizations planned on hiring), and
- "Creating a data-driven culture" - as only $32.4 \%$ of the respondents "indicate that their firm has achieved this outcome" and $" 80.9 \%$ of executives agree that cultural challenges (people + process) represent the greatest barrier to overcome";

- Technology related - as regards: (a). the "data management environment" making the "shift from traditional data center environments to cloud computing environments"; and (b). "data applications" - making "the shift from the use and deployment of data for traditional reporting applications to nearreal time dashboards and real-time interactive operations".

- "Data threat" - related to: (a). the "inability to compete on data | lack of agility | data-driven competitors (54.4\%); 


\begin{tabular}{|c|c|}
\hline $\begin{array}{l}\text { finding people who can identify and } \\
\text { leverage the business opportunities in Big } \\
\text { Data; } \\
\text { - Finding the best leadership structure - as } \\
\text { quite a variety of positions were considered } \\
\text { the most appropriate to lead the big data } \\
\text { related initiatives (Chief Information Officer, } \\
\text { Chief Technology Officer/Chief Architect, } \\
\text { "Other"; } \\
\text { "Creating a Big Data environment to } \\
\text { accelerate time-to-answer" and developing } \\
\text { an ecosystem of Big Data. }\end{array}$ & $\begin{array}{l}\text { and (b). cyber security I data privacy } \\
\text { - }(45.6 \%) \text {. } \\
\text { Defining the "role and mandate of the } \\
\text { Chief Data Officer (CDO)" }- \text { as } \\
\text { consensus is still missing with regard to: } \\
\text { (a). the primary responsibility for data } \\
\text { strategy and results; (b). the primary } \\
\text { responsibility of the CDO; (c). the } \\
\text { background for a successful CDO; (d). } \\
\text { the long term role of the CDO; } \\
\text { The (increasing) threat of disruption and } \\
\text { displacement from both the tech } \\
\text { companies and those from within their } \\
\text { own industry - more agile and adapted } \\
\text { to the challenges of big data. }\end{array}$ \\
\hline $\begin{array}{l}\text { dealt with the challenges of Big Data, while } \\
\text { more focused and goal-oriented approach } \\
\text { concept, its business applications and poten } \\
\text { of appropriate structures and cultures at bu } \\
\text { benefits of data strategies. Nevertheless, as } \\
\text { the ways to handle the (known) challenges } \\
\text { occur, making the search for innovative app } \\
\text { improvement. }\end{array}$ & $\begin{array}{l}\text { impact; (b). the design and implemente } \\
\text { hess level, able to support and enhance } \\
\text { usinesses and their managers get insight } \\
\text { Big Data, new (and/or unknown) challer } \\
\text { aches and solutions a process of contin }\end{array}$ \\
\hline
\end{tabular}

\section{Conclusions}

Over the last few years, Big Data and Business Analytics have emerged as a driving force able to determine transformational changes in the ways companies are doing businesses, while reconfiguring entire industries; in the same time, academia, (business specialized) media, and BDA solution providers / consultant companies have started to document and/or support this process - by searching for and pointing out:

- the most significant challenges of BDA (in terms of both risks/threats and opportunities):

"There are three main contributing factors leading to emergence of big data problems in organizations: digitalization of business processes and associated data, accumulation of additional data, and aspirations to extract actionable knowledge from data and/or monetize data" (Géczy, 2014); but, "trough exploratory, detailed analyses of big data, a user organization can discover new facts about their customers, markets, partners, costs, and operations - then use that information for business advantage" (Russom, 2011);

- the most appropriate (dedicated) BDA applications/solutions:

"Five broadly applicable ways to leverage big data that offer transformational potential to create value and have implications for how organizations will have to be designed, organized, and managed: (1) creating transparency; (2) enabling experimentation to 
discover needs, expose variability, and improve performance; (3) segmenting populations to customize actions; (4) replacing/supporting human decision making with automated algorithms; and (5) innovating new business models, products, and services" (Manyika, et al., 2011);

- the main characteristics that define a BDA leading business:

"Organizations that capitalize on big data stand apart from traditional data analysis environments in three key ways: they pay attention to data flows as opposed to stocks; they rely on data scientists and product and process developers rather that data analysts; they are moving analytics away from the IT function and into core business, operational and production functions" (Davenport, Barth, \& Bean, 2012);

- the main (types of) benefits that embracing BDA might provide:

"Eight Ways Big Data and Al are Changing the Business World: (1) improved business intelligence; (2) understanding, targeting, and serving customers; (3) changing the ways social media is used; (4) the introduction of customer responsive products; (5) enhance fraud prevention abilities; (6) improvements in efficiency; (7) enable constant customer support; and (8) reduced costs" (Mills, 2018).

\section{References}

Bean, R. (2018). How Big Data and Al are driving business innovation in 2018. MIT Sloan Management Review Webinar. http://newvantage.com/wp-content/uploads/2018/07/MITBean-Webinar-2018-slides-FINAL-071818.pdf.

Burris, P. (2018). Wikibon's 2018 Big Data and Analytics Market Share Report. March 6. https://wikibon.com/wikibons-2018-big-data-analytics-market-share-report/.

Davenport, T. H., Barth, P., \& Bean, R. (2012). How'big data'is different. MIT Sloan Management Review. July 30.

Dresner Advisory Services, LLC. (2017). 2017 Big Data Analytics Market Study. https://www.microstrategy.com/getmedia/cd052225-be60-49fd-ab1c4984ebc3cde9/Dresner-Report-Big_Data_Analytic_Market_Study-WisdomofCrowdsSeries2017.pdf.

Géczy, P. (2014). Big Data Characteristics. The Macrotheme Review, 3(6), 94-104.

IDC. (2018). Revenues for Big Data and Business Analytics Solutions Forecast to Reach $\$ 260$ Billion in 2022, Led by the Banking and Manufacturing Industries, According to IDC. https://www.idc.com/getdoc.jsp?containerld=prUS44215218.

Kobielus, J. (2018). Wikibon's 2018 Big Data Analytics Trends and Forecast. February 28. https://wikibon.com/wikibons-2018-big-data-analytics-trends-forecast/.

LaValle, S., Lesser, E., Shockley, R., Hopkins, M. S., \& Kruschwitz, N. (2011). Big data, analytics and the path from insights to value. MIT sloan management review, 52(2), 21.

Manyika, J., Chui, M., Brown, B., Bughin, J., Dobbs, R., Roxburgh, C., Hung Byers, A. (2011). Big Data: the next frontier for innovation, competition and productivity. McKinsey\&Company. https://www.mckinsey.com/ /media/McKinsey/Business\%20Functions/McKinsey\%20Digital/ Our\%20Insights/Big\%20data\%20The\%20next\%20frontier\%20for\%20innovation/MGI_big_d ata_exec_summary.ashx.

McKinsey Analytics. (2018). Analytics comes of age. January. https://www.mckinsey.com/ /media/McKinsey/Business\%20Functions/McKinsey\%20Analyti cs/Our\%20Insights/Analytics\%20comes\%20of\%20age/Analytics-comes-of-age.ashx. 
Mills, T. (2018). Eight Ways Big Data and Al are Changing the Business World. Forbes, https://www.forbes.com/sites/forbestechcouncil/2018/07/31/eight-ways-big-data-and-ai-arechanging-the-business-world/\#7cf3ef6f45b6.

NewVantage Partners LLC. (2018). Big Data Executive Survey 2018. Data and Innovation. How Big Data and $\mathrm{Al}$ are Driving Business Innovation. http://newvantage.com/wpcontent/uploads/2018/01/Big-Data-Executive-Survey-2018-Findings-1.pdf.

NewVantage Partners LLC. (2012). Big Data Executive Survey 2012. http://newvantage.com/wpcontent/uploads/2012/12/NVP-Big-Data-Survey-2012-Consolidated-Report-Final1.pdf.

Ogrean, C. (2018). Relevance of Big Data for Business and Management. Exploratory Insights (Part I). Studies in Business and Economics, 13(2), 153-163.

Rothaermel, F. T. (2017). Strategic Management. McGraw Hill Education. New York.

Russom, P. (2011). Big data analytics. TDWI Best Practices Report, 19(4), 1-34.

Statista. (2017). Statista. Big Data Dossier. https://www.statista.com 